\title{
Eksperimentasi Model Pembelajaran Kooperatif Tipe Teams Games Tournament (TGT) Berbantuan Software Cabri 3d di Tinjau dari Kemampuan Koneksi Matematis Siswa
}

\author{
Fredi Ganda Putra \\ IAIN Raden Intan Lampung: fredigpsw@gmail.com
}

Submitted : 10-08-2015, Revised : 19-10-2015, Accepted : 16-12-2015

\begin{abstract}
This study aims to determine: (1) Which provides better learning achievement between students who are subjected to cooperative learning model type TGT assisted Cabri 3D, TGT, and direct learning; (2) which have better learning achievement among students who have high, medium, or low math connection ability; (3) In each category of mathematical connection capabilities, which have better learning achievement between students are subject to cooperative learning model TGT type assisted by Cabri 3D, TGT, and direct learning, and (4) In each category of learning model, which Who have better learning achievement between students with high, medium, or low math connection ability. The type of this research is quasi experimental research with factorial design $3 \times 3$. The population in this research is all students of class IX SMP in Metro City Lesson Year 2015/2016. The sample in this research was obtained by using stratified cluster random sampling technique. The sample in this study consisted of 278 students with details of 90 students in the TGT assisted model group Cabri 3D, 95 students in the TGT learning model group, and 93 students in the direct learning model group. Instruments used to collect data are tests of mathematical ability and test achievement test. Hypothesis testing used two way analysis of variance with unequal cell. The results of this research are: 1) TGT assisted learning model Cabri 3D resulted better learning achievement compared to TGT learning model and direct learning model, and TGT learning model yielded better achievement compared with direct learning model. 2) Students with high category mathematical connection ability and students with medium category mathematical connection ability have the same learning achievement, while both have better learning achievement than students with low category mathematical connection ability. 3) In each type of mathematical connection capability (high, medium, and low), the application of TGT-assisted learning model Cabri 3D resulted in better learning achievement compared to TGT learning model and direct learning model, and TGT learning model resulted in better achievement compared with model Direct learning. 4) In each learning model (TGT assisted Cabri 3D, TGT, and direct), students with high category mathematical connection ability and students with medium category mathematical connection ability have the same learning achievement, while both have better learning achievement than students with ability Low category mathematical connection.
\end{abstract}

Keywords: Cabri 3D; Connection; TGT. 


\begin{abstract}
Abstrak
Penelitian ini bertujuan untuk mengetahui:(1)manakah yang memberikanprestasi belajar lebih baik antara siswa yang dikenakan model pembelajaran kooperatif tipe TGT berbantuan Cabri 3D, TGT, dan pembelajaran langsung; (2) manakah yang mempunyaiprestasi belajar lebih baik antara siswa yang memiliki kemampuan koneksi matematika kategori tinggi, sedang, atau rendah; (3) Pada masing-masing kategori kemampuan koneksi matematika, manakah yang mempunyai prestasi belajar lebih baik antara siswa dikenakan model pembelajaran kooperatif tipe TGT berbantuan Cabri 3D, TGT, dan pembelajaran langsung, dan (4) Pada masing-masing kategori model pembelajaran, manakah yang mempunyai prestasi belajar lebih baik antara siswa dengan kemampuan koneksi matematika kategori tinggi, sedang, atau rendah. Jenis penelitian ini adalah penelitian eksperimen semu dengan desain faktorial $3 \times 3$. Populasi pada penelitian ini adalah seluruh siswa kelas IX SMP di Kota Metro Tahun Pelajaran 2015/2016. Sampel dalam penelitian ini diperoleh dengan menggunakan teknik stratified cluster random sampling. Sampel dalam penelitian ini terdiri atas 278 peserta didik dengan rincian 90 siswa pada kelompok model TGT berbantuan Cabri 3D, 95 siswa pada kelompok model pembelajaran TGT, dan 93 siswa pada kelompok model pembelajaran langsung. Instrumen yang digunakan untuk mengumpulkan data adalah tes kemampuan mkoneksi matematika dan tes prestasi belajar. Pengujian hipotesis menggunakan analisis variansi dua jalan dengan sel tak sama. Hasil penelitian ini adalah:1) Model pembelajaran TGT berbantuan Cabri 3D menghasilkan prestasi belajar lebih baik dibandingkan model pembelajaran TGT dan model pembelajaran langsung, serta model pembelajaran TGT menghasilkan prestasi lebih baik dibandingkan dengan model pembelajaran langsung. 2) Siswa dengankemampuan koneksi matematis kategori tinggi dan siswa dengan kemampuan koneksi matematis kategori sedang mempunyai prestasi belajar yang sama, sementara keduanyamempunyai prestasi belajar yang lebih baik dibandingkan siswa dengankemampuan koneksi matematis kategori rendah. 3) Pada masing-masing tipe kemampuan koneksi matematis (tinggi, sedang, dan rendah), penerapan model pembelajaran TGT berbantuan Cabri 3D menghasilkan prestasi belajar lebih baik dibandingkan model pembelajaran TGT dan model pembelajaran langsung, serta model pembelajaran TGTmenghasilkan prestasi lebih baik dibandingkan dengan model pembelajaran langsung. 4) Pada masing-masing model pembelajaran (TGT berbantuan Cabri 3D, TGT,dan langsung), siswa dengankemampuan koneksi matematis kategori tinggi dan siswa dengan kemampuan koneksi matematis kategori sedang mempunyai prestasi belajar yang sama, sementara keduanyamempunyai prestasi belajar yang lebih baik dibandingkan siswa dengankemampuan koneksi matematis kategori rendah.
\end{abstract}

Kata Kunci: Cabri 3D; Koneksi; TGT.

\title{
PENDAHULUAN
}

Salah satu tujuan diwajibkan adanya mata pelajaran matematika dalam kurikulum SMP adalah agar seorang siswa mempunyai kemampuan matematis yang baik sehingga akan bermanfaat dalam kehidupan sehari-harinya. Pada kenyataannya, tujuan tersebut hingga saat ini belum dapat dicapai secara optimal karena masih banyak siswa yang mengalami kesulitan dalam mempelajari materi-materi pada mata pelajaran matematika. 
Supartono dalam Misdalina, dkk. (2009: 62) menyatakan bahwa kenyataan yang masih sering ditemui di sekolah yaitu masih banyak siswa yang mengalami kesulitan dalam mempelajari matematika, sehingga hasil belajar siswa belum optimal. Belum optimalnya hasil belajar matematika juga terjadi di Kota Metro Propinsi Lampung. Berdasarkan hasil laporan ujian nasional tahun pelajaran 2012/2013, nilai rata-rataujian nasional mata pelajaran matematika tingkat SMP di Kota Metro adalah 5,29. Nilai rata-rata mata pelajaran Matematika tersebut masih berada dibawah rata-rata nilai ujian nasionalmata pelajaran IPA $(6,08)$, Bahasa Inggris $(5,35)$ dan Bahasa Indonesia $(7,37)$ (BSNP, 2013). Salah satu sub materi yang dianggap sulit oleh siswa pada mata pelajaran matematika di SMP adalah geometri. Hal ini sependapat dengan Abdussakir (2009) yang menyatakan bahwa pada tingkatan SMP masih banyak siswa belum memahami konsep-konsep geometri.Salah satu sub materi geometri adalah bangun ruang. Pada materi tersebut masih banyak siswaSMPdi Kota Metro yang mengalami kesulitan dalam menyelesaikan soal. Kenyataan ini tampak pada daya serap kemampuan siswaSMPdi Kota Metro dalam memahami sifat dan unsur bangun ruang serta menggunakannya dalam pemecahan masalah sebesar 38,88\% (BSNP, 2013). Rendahnya daya serap pada materi bangun ruang ini menandakan bahwa siswa masih mengalami kesulitan dalam mempelajari serta memahami materi ini.

Penerapan model pembelajaran kooperatif merupakan salah satu cara untuk mengatasi permasalahan tersebut. Pembelajaran kooperatifdidasarkan padakeyakinan bahwapembelajaranyang paling efektif apabilasiswasecara aktifterlibat dalamberbagi idedan bekerja samauntuk menyelesaikantugas-tugasakademik (Zakaria and Iksan, 2007: 36), sehingga dapat dikatakan bahwa pembelajaran kooperatif bernaung dalam teori konstruktivis (Trianto, 2012: 56). Menurut Slavin (2005: 4-5) "penggunaan pembelajaran kooperatif dapat meningkatkan prestasi belajar para siswa dan dapat mengembangkan hubungan antar kelompok, penerimaan terhadap teman sekelas yang lemah dalam bidang akademik, dan meningkatkan rasa harga diri". Dari beberapa pendapat tersebut maka penelitian ini menggunakan model pembelajaran kooperatif dalam pembelajaran matematika di kelas.

Di dalam penelitian ini peneliti menggunakan model pembelajaran kooperatif tipe Teams Games Tournament (TGT). Pemilihan model pembelajaran ini dirasa cocok untuk digunakan pada materi geometri, karena pada model pembelajaran kooperatif tipe TGT, siswa diminta untuk menyelesaikan masalah secara berkelompok dan kemudian menyelesaikan masalah dalam games pada turnamen secara individu yang mana hasil turnamen akan mempengaruhi nilai kelompok.Juga didasarkan pada penelitian yang dilakukan oleh Wyk (2011) dan Awofala, et al. (2012) yang memberikan hasil bahwa siswa yang dikenakan model pembelajaran kooperatif tipe TGT menghasilkan prestasi belajar yang lebih baik dibandingkan dengan siswa yang dikenakan model pembelajaran konvensional. Akan tetapi, penelitian terdahulu ada juga yang menyatakan bahwa model pembelajaran kooperatif tipe TGT menghasilkan prestasi belajar yang tidak maksimal, seperti penelitian yang dilakukan oleh Prabawanti (2012) menyimpulkan bahwa model pembelajaran kooperatif tipe STADmenghasilkan prestasi belajar yang lebih baik dibandingkan dengan model pembelajaran kooperatif tipe TGT. Berdasarkan hal tersebut, peneliti merasa model pembelajaran kooperatif tipe TGT perlu dibantu oleh media pembelajaran dalam pelaksanaannya.Manfaat media pembelajaran adalah untuk meningkatkan kualitas hasil 
belajar siswa(Kemp dan Dayton dalam Arsyad, 2007: 21). Salah satu media yang bisa digunakan dalam pembelajaran pada materi geometri adalah Software Cabri 3D. Software Cabri 3D adalah salah satu dynamic software geometri yang bisa membantu dalam proses pembelajaran matematika khususnya dalam memahami konsep geometri bangun ruang atau dimensi tiga. Peneliti menduga bahwa penggunaan software Cabri $3 D$ dalam proses pembelajaran matematika dapat meningkatkan hasil belajar peserta didik pada materi bangun ruang sisi datar segi empat, pemikiran ini juga di dasari pada penelitian yang telah dilakukan oleh Subroto (2011) yang memberikan hasil bahwa kemampuan spasialsiswayangdiajarkanmenggunakansoftware Cabri3Dlebih baik daripadasiswayang diajar denganpembelajaran langsung. Oleh karena itu, peneliti tertarik untuk membandingkan penerapan model pembelajaran kooperatif tipe TGT berbantuan software Cabri 3D dan model pembelajaran kooperatif tipe TGTpada penelitian ini.

Selain model pembelajaran dan media pembelajaran, guru sebaiknyajuga memperhatikankemampuan koneksi matematissiswa. Tanpa kemampuan koneksi matematika maka siswa wajib mengingat terlalu banyak konsep dan prosedur matematika yang saling terpisah. NCTM (dalam Linto :2012) menyatakan bahwa tujuan koneksi matematika diberikan pada siswa di sekolah menengah adalah agar siswa dapat: (1) Mengenali representasi yang ekuivalen dari suatu konsep yang sama, (2) Mengenali hubungan prosedur satu representasi ke prosedur representasi yang ekuivalen, (3) Menggunakan dan menilai koneksi beberapa topic matematika, dan (4) Menggunakan dan menilai koneksi antara matematika dan disiplin ilmu lain.

Penelitian ini bertujuan untuk mengetahui: (1) manakah yang menghasilkanprestasi belajar matematika lebih baik antara model pembelajaran kooperatif tipe TGT berbantuansoftware Cabri 3D(TGTC3D), model pembelajaran kooperatif tipe TGT atau model pembelajaran langsung pada materi bangun ruang sisi datar di Kota Metro;(2)manakah yang mempunyai pretasi belajar lebih baik antara siswa dengan Kemampuan Koneksi Matematiskategori tinggi, sedang, atau rendah pada materi bangun ruang sisi datar di Kota Metro; (3) pada masing-masingkategoriKemampuan Koneksi Matematis (tinggi, sedang, dan rendah), manakah yang menghasilkanprestasi belajar lebih baik antara model pembelajaran kooperatif tipe TGT berbantuansoftware Cabri 3D(TGTC3D), model pembelajaran kooperatif tipe TGT atau model pembelajarn langsung pada materi bangun ruang sisi datar di Kota Metro; dan (4) pada masing-masing model pembelajaran (TGTC3D, TGT dan langsung), manakah yang mempunyai prestasi belajar lebih baik antara siswadenganKemampuan Koneksi Matematiskategori tinggi, sedang, atau rendah.

\section{METODE PENELITIAN}

Penelitian ini termasuk penelitian eksperimental semu yang dirancang dengan desain faktorial $3 \times 3$. Populasi pada penelitian ini adalah seluruh siswa kelas IX SMP di Kota Metro Provinsi Lampung Tahun Pelajaran 2014/2015. Sampel penelitian sebanyak 268 responden yang terdiri dari 90 siswa sebagai kelompok eksperimental 1 yang diterapkan model pembelajaran kooperatif tipe Teams Games Tournament (TGT) berbantuan software Cabri $3 D, 85$ siswa sebagai kelompok eksperimental 2 yang diterapkan model pembelajaran 
kooperatif tipe Teams Games Tournament (TGT), dan 93 siswa dari kelompok kontrol yang diterapkan model pembelajaran langsung.

Variabel dalam penelitian ini terbagi menjadi dua, yaitu variabel terikat dan variabel bebas. Variabel terikat dalam penelitian ini adalah prestasi belajar matematika pada materi bangun ruang sisi datar, sedangkan variabel bebas dalam peneletian ini adalah model pembelajaran (TGTC3D, TGT, dan Langsung) dan Kemampuan Koneksi Matematis (tinggi, sedang, dan rendah). Teknik pengumpulan datamenggunakan metode dokumentasi, metode observasi, dan metode tes. Instrumen penelitian terdiri atas tes kemampuan koneksi matematis pada materi bangun datar dan tes prestasi belajar pada materi bangun ruang sisi datar.

Uji coba instrumen teskemampuan koneksi matematisdan tes prestasi belajar matematika dilakukan di SMP N 8 Metro pada kelas IX B dengan jumlah responden sebanyak31 siswa. Uji coba instrumen teskemampuan koneksi matematisdan tes prestasi belajar matematika mengacu pada kriteria yaitu validitas isi, tingkat kesukaran $(0,30 \leq T K \leq 0,70)$, dayapembeda $(D B \geq 0,3)$, dan reliabilitas $\left(r_{11} \geq 0,7\right)$. Jumlah butir item pada teskemampuan koneksi matematisyang diujicobakan sebanyak 10 butir, sedangkan jumlah butir soal tes prestasi belajar matematika sebanyak 30 butir soal. Hasil ujicoba instrumen teskemampuan koneksi matematis diperoleh5 butir soal yang dapat digunakan, sedangkan hasil uji coba instrumen tes prestasi belajar matematika sebanyak 20 butir soal yang digunakan untuk alat pengambil data.

Uji keseimbangan dikenakan pada data kemampuan awal. Dalam penelitian ini, uji keseimbangan menggunakan analisis variansi satu jalan. Sebagai prasyarat uji keseimbangan, dilakukan uji normalitas (metode Lilliefors) dan uji homogenitas (metode Bartlett) pada kemampuan awal. Uji prasyarat untuk analisis uji hipotesis menggunakan uji normalitas (metode Lilliefors) dan uji homogenitas (metode Bartlett), sedangkan uji hipotesisnya menggunakan uji anava dua jalan dengan sel tak sama yang dilanjutkan dengan uji komparasi ganda dengan metode Scheffe'jika hipotesis nol ditolak.

\section{HASIL PENELITIAN DAN PEMBAHASAN}

Hasil uji prasyarat pada data kemampuan awal dan prestasi belajar menyimpulkan bahwa semua sampel berasal dari populasi yang berdistribusi normaldan populasi-populasi mempunyai variansi yang sama. Hal ini ditunjukkan pada hasil perhitungan uji normalitas pada data kemampuan awal dan prestasi belajar. Pada data kemampuan awal, hasil perhitungan uji normalitas kelompok model pembelajaran (TGTC3D, TGT, dan langsung) menyimpulkan bahwa semua $H_{0}$ diterima, sehingga sampel berasal dari populasi yang berdistribusi normal dan hasil perhitungan uji homogenitas pada kelompok model pembelajaran (TGTC3D, TGT, dan langsung) juga menyimpulkan bahwa semua $H_{0}$ diterima, sehingga sampel berasal dari populasi yang homogen. Padadata prestasi belajar matematika, hasil uji normalitas kelompok model pembelajaran (TGTC3D, TGT, dan langsung) dan kelompok teskemampuan koneksi matematis (tinggi, sedang, dan rendah) menyimpulkan bahwa semua $H_{0}$ diterima, sehingga sampel berasal dari populasi yang berdistribusi normal dan hasil perhitungan uji homogenitas pada kelompok model pembelajaran (TGTC3D, TGT, dan langsung) dan kelompok kemampuan koneksi matematis (tinggi, sedang, dan rendah)juga menyimpulkan bahwa semua $H_{0}$ diterima, sehingga sampel 
berasal dari populasi yang homogen. Pada data kemampuan awal dilakukan uji keseimbangan antar kelompok model pembelajaran untuk mengetahui apakah populasi antara kelompok model pembelajaran kooperatif tipe Teams Games Tournament (TGT) berbantuan software Cabri 3D, model pembelajaran kooperatif tipe Teams Games Tournament (TGT), dan model pembelajaran langsung mempunyai kemampuan matematika yang sama. Berdasarkan hasil uji keseimbangan, disimpulkan bahwa sampel dari populasi kelompok model pembelajaran (TGTC3D, TGT, dan langsung) dalam keadaan seimbang.

Selanjutnya, dilakukan uji analisis variansi dua jalan sel tak sama pada data prestasi belajar. Rangkuman uji analisis variansi dua jalan sel tak sama disajikan pada Tabel 1. berikut.

Tabel 1. Rangkuman Analisis Variansi Dua Jalan

\begin{tabular}{|c|c|c|c|c|c|c|}
\hline Sumber & $I K$ & $d k$ & $R K$ & $F_{\text {obs }}$ & $F_{\text {tab }}$ & Kesim! \\
\hline $\begin{array}{c}\text { Model } \\
\text { Pembelajaran(A } \\
\text { ) }\end{array}$ & 9298,8245 & 2 & $\begin{array}{c}4639,908 \\
2\end{array}$ & $\begin{array}{c}11,632 \\
4\end{array}$ & 3 & $H_{0 A d i t}$ \\
\hline $\begin{array}{c}\text { Kemampuan } \\
\text { Koneksi } \\
\text { Matematis(B) }\end{array}$ & 7102,4304 & 2 & $\begin{array}{c}3556,224 \\
7\end{array}$ & 8,9214 & 3 & $H_{0 B}$ dit \\
\hline Interaksi (AB) & 3587,7685 & 4 & 896,9421 & 2,2500 & $\begin{array}{c}2,3 \\
7\end{array}$ & $H_{0 A B}$ diterima \\
\hline $\begin{array}{l}\text { Galat } \\
\text { total }\end{array}$ & $\begin{array}{c}107343,969 \\
4 \\
127324,003 \\
8 \\
\end{array}$ & $\begin{array}{c}26 \\
9 \\
27 \\
7\end{array}$ & 399,0482 & & & \\
\hline
\end{tabular}

Berdasarkan Tabel 1, dapat ditarik kesimpulan bahwa: (1) pada model pembelajaran (A), terdapat perbedaan prestasi belajar antara model pembelajaran Teams Games Tournament (TGT) berbantuan software Cabri 3D, Teams Games Tournament(TGT), langsung; (2) pada kemampuan koneksi matematis (B), ketiga kategorikemampuan koneksi matematis memberikan efek yang berbeda terhadap prestasi belajar matematika; (3) pada interaksi $(A B)$, tidak terdapat interaksi antara tipe kemampuan koneksi matematis dan model pembelajaran terhadap prestasi belajar matematika. Dikarenakan $H_{O A}$ dan $H_{0 B}$ ditolak, maka perlu dilakukan uji lanjut pasca anava untuk mengetahui secara signifikan tentang perbedaan rerata. Rangkuman rerata marginal disajikan pada Tabel 2. berikut:

Tabel 2. Rerata Marginal dari Model Pembelajaran dan Kemampuan Koneksi Matematis

\begin{tabular}{ccccc}
\hline \multirow{2}{*}{ Model pembelajaran } & \multicolumn{2}{c}{ Kemampuan Koneksi Matematis } & \multirow{2}{*}{ Rerata Marginal } \\
& Tinggi & Sedang & Rendah & \\
\hline TGT Cabri 3D & 80,3659 & 58,4091 & 71,8519 & 72,4444 \\
TGT & 70,0000 & 54,3750 & 65,5000 & 62,4737 \\
Langsung & 55,0000 & 54,8077 & 56,5909 & 55,3226 \\
Rerata Marginal & 67,9339 & 55,5114 & 65,1449 & 63,3094 \\
\hline
\end{tabular}


Pada hipotesis pertama, telah diketahui pada perhitungan analisis variansi dua jalan dengan sel tak sama di atas bahwa $H_{0 A}$ ditolak, sehingga perlu dilakukan uji komparasi ganda antar baris (antar model pembelajaran). Rangkuman uji komparasi ganda antara baris disajikan dalam Tabel 3. berikut:

Tabel 3. Rangkuman Uji Komparasi Ganda antar Baris

\begin{tabular}{ccccc}
\hline No. & $H_{0}$ & $F_{\text {hit }}$ & $2 . F_{0,05: 2 \text { in }}$ & Keputusan Uji \\
\hline 1 & $\mu_{1}=\mu_{2}$ & 11,5140 & 6,00 & $H_{0}$ ditolak \\
2 & $\mu_{1}=\mu_{3 .}$ & 33,6010 & 6,00 & $H_{0}$ ditolak \\
3 & $\mu_{2}=\mu_{3}$ & 6,0224 & 6,00 & $H_{0}$ ditolak \\
\hline
\end{tabular}

Berdasarkan Tabel 3pada hipotesis nol yang pertama, diperoleh kesimpulan bahwa terdapat perbedaan prestasi belajar pada materi bangun ruang sisi datar antara siswa yang mendapat model pembelajaran kooperatif tipe TGTberbantuan software Cabri 3D dan model pembelajarankooperatif tipe TGT. Dari Tabel 2, dapat disimpulkan bahwa prestasi belajar siswa yang mendapat model pembelajaran kooperatif tipe TGTberbantuan software Cabri 3D lebih baik dibandingkan prestasi belajar siswa yang mendapat model pembelajaran kooperatif tipe TGT. Hasil ini sekaligus melengkapi penelitian-penelitian sebelumnya terkait media berbasis komputer seperti Güven \& Kosa (2008), Irsadi (2012), serta Andriyati \& Rudhito (2013) yang memberikan hasil bahwa penggunaan software Cabri 3D dapat meningkatkan kemampuan spasial siswa dan pemahaman konsep sehingga prestasi belajar siswa menjadi lebih baik. Selanjutnya pada hipotesis nol yang kedua di Tabel 3 diperoleh kesimpulan bahwa terdapat perbedaan prestasi belajar pada materi bangun ruang sisi datar antara siswa yang mendapat model pembelajaran TGTberbantuan software Cabri $3 D$ dan model pembelajaran langsung. Dari Tabel2, dapat disimpulkan bahwa prestasi belajar matematika siswa yang mendapat model pembelajaran TGTberbantuan software Cabri 3D lebih baik dibandingkan prestasi belajar siswa yang mendapat model pembelajaran langsung. Hasil ini juga sesuai dengan penelitian Tran (2013), Tarim \& Akdenis (2008), Özs oy \& Yildiz (2004) yang memberikan hasil bahwa model pembelajaran kooperatif dapat meningkatkan prestasi belajar matematika dan menghasilkan prestasi belajar yang lebih baik dibandingkan model pembelajaran langsung. Pada hipotesis nol yang ketiga di Tabel 3, dapat disebutkan bahwa terdapat perbedaan prestasi belajar matematika pada materi bangun ruang sisi datar antara siswa yang mendapat model pembelajaran TGT dan Langsung. Dari Tabel2, dapat disimpulkan bahwa prestasi belajar siswa yang mendapat model pembelajaran TGT lebih baik dibandingkan prestasi belajar siswa yang mendapat model pembelajaran langsung. Hal ini sejalan dengan pendapat Wyk (2011) yang menyatakan bahwa pembelajaran model pembelajaran Teams Games Tournament (TGT) menghasilkan prestasi belajar yang lebih baik dibandingkan dengan menggunakan pembelajaran langsung.

Pada hipotesis kedua, telah diketahui pada perhitungan analisis variansi dua jalan dengan sel tak sama di atas bahwa $H_{0 B}$ ditolak sehingga perlu dilakukan uji komparasi ganda antar kolom (antar tipe Kemampuan Koneksi Matematis). Rangkuman uji komparasi ganda antara kolom disajikan dalam Tabel 4 berikut. 
Tabel 4. Rangkuman Uji Komparasi Ganda antar Kolom

\begin{tabular}{ccccc}
\hline No. & $H_{0}$ & $F_{\text {hit }}$ & $2 . F_{0,05: 2 \mathrm{~m}}$ & Keputusan Uji \\
\hline 1 & $\mu_{\mathrm{s}}=\mu_{\mathrm{s}}$ & 19,7023 & 6,00 & $H_{0}$ ditolak \\
2 & $\mu_{\mathrm{s}}=\mu_{3}$ & 0,8565 & 6,00 & $H_{0}$ diterima \\
3 & $\mu_{\mathrm{s}}=\mu_{3}$ & 8,9946 & 6,00 & $H_{0}$ ditolak \\
\hline
\end{tabular}

Berdasarkan Tabel 4 pada hipotesis nol yang pertama, diperoleh kesimpulan bahwa terdapat perbedaan prestasi belajar pada materi bangun ruang sisi datar antara siswa yang memiliki kemampuan koneksi matematis kategori tinggi dan siswa yang memiliki kemampuan koneksi matematis kategori rendah.

Pada hipotesis ketiga, telah diketahui pada perhitungan analisis variansi dua jalan dengan sel tak sama di atas bahwa $H_{O A B}$ diterima sehingga tidak perlu dilakukan uji komparasi ganda antar sel. Berdasarkan hal tersebut, dapat disimpulkan bahwa pada masing-masing tipe kemampuan koneksi matematis, model pembelajaran kooperatif tipe TGT berbantuan software Cabri 3D menghasilkan prestasi belajar lebih baik dibandingkan model pembelajaran kooperatif tipe TGT dan langsung, serta model pembelajaran kooperatif tipe TGT model pembelajaran TGT dan langsung. Hasi sepertil ini diduga karena sering kali guru tidak menggunakan pembelajaran kooperatif pada proses belajar mengajar. Pada saat peneliti menerapkan model pembelajaran kooperatif tipe TGT, siswa dengan kemampuan koneksi matematis kategori tinggi tertarik dalam belajar,sehingga penerapan model pembelajaran kooperatif tipe TGT memberikan prestasi belajar yang lebih baik daripada model pembelajaran langsung. Penggunaan media komputer dalam pembelajaran juga diduga jarang guru lakukan. Sehingga, pada waktu peneliti menerapkan model pembelajaran kooperatif tipe TGTyang dikombinasikan dengan software Cabri 3D, siswa dengan kemampuan koneksi matematis kategori rendah semakin antusias dalam belajar. $\mathrm{Hal}$ ini yang diduga berpengaruh dalam menyebabkan siswa yang memiliki kemampuan koneksi matematis kategori rendah, model pembelajaran kooperatif tipe TGT berbantuan software Cabri 3D memberikan prestasi belajar yang lebih baik dibandingkan dengan model pembelajaran kooperatif tipe TGT dan model pembelajaran langsung, model pembelajaran kooperatif tipe TGTmemberikan prestasi belajar yang lebih baik dibandingkan dengan model pembelajaran langsung.

Pada hipotesis keempat, telah diketahui pada perhitungan analisis variansi dua jalan dengan sel tak sama di atas bahwa $H_{0 A B}$ diterima sehingga tidak perlu dilakukan uji komparasi ganda antar sel. Berdasarkan hal tersebut, dapat disimpulkan bahwa pada masing-masing model pembelajaran, siswa dengankemampuan koneksi matematis kategori tinggidan siswa dengan kemampuan koneksi matematis kategori sedangmempunyai prestasi belajar sama, sementara keduanya mempunyai prestasi belajar lebih baik dibandingkan dengan siswa yang memiliki kemampuan koneksi matematis kategori rendah. Pada hasil penelitian yang keempat terdapat beberapa perbedaan dengan hipotesis penelitian. Perbedaan yang pertama yaitu hipotesis yang menyebutkan bahwa "pada penerapan model pembelajaran TGT berbantuan software Cabri 3D, siswa dengan kemampuan koneksi matematis kategori tinggi mempunyai prestasi belajar yang lebih baik dibandingkan siswa dengan kemampuan koneksi matematis kategori sedang maupun rendah, sementara siswa dengan kemampuan koneksi matematis kategori sedangmempunyai prestasi belajar yang 
lebih baik dibandingkan siswa dengan kemampuan koneksi matematis kategori rendah. Perbedaan hasil dengan hipotesis penelitian tersebut diduga penyebabnya adalah faktor luaran. Pada penerapan model pembelajaran kooperatif tipe TGT berbantuan software Cabri 3D, peneliti mendapat beberapa kesulitan pada pelaksanaannya. Beberapa faktor kesulitan tersebut yaitu sarana yang tidak memadai, peraturan sekolah yang melarang siswanya membawa alat elektronik seperti komputer/laptop dan kondisi laboratorium komputer yang sudah tidak bisa digunakan. Faktor-faktortersebut merupakan masalah yang tidak bisa peneliti kontrol dalam penerapan model ini, sehingga siswa dengan kemampuan koneksi matematis kategori tinggi memiliki prestasi yang sama dengan siswa yang memiliki kemampuan koneksi matematis kategori sedang, dan keduanya memiliki prestasi belajar yang lebih baik daripada kemampuan koneksi matematis kategori rendah.

Perbedaan yang kedua adalah hipotesis yang menyebutkan bahwa "pada penerapan model pembelajaran langsung, siswa dengan kemampuan koneksi matematis kategori tinggi, sedang, maupun rendah mempunyai prestasi belajar yang sama". Perbedaan tersebut diduga karena siswa dengan kemampuan koneksi matematis kategori tinggi dan sedang cenderung lebih aktif dalam pembelajaran dibandingkan siswa dengan kemampuan koneksi matematis kategori rendah. Sehingga pada penerapan model pembelajaran ini, siswa dengan kemampuan koneksi matematis kategori tinggi dan sedang memiliki prestasi belajar yang lebih baik dibandingkan dengan siswa yang memiliki kemampuan koneksi matematis kategori rendah, sementara siswa dengan kemampuan koneksi matematis kategori tinggi memiliki prestasi belajaryang sama dengan siswa yang memiliki kemampuan koneksi matematis kategori sedang.

\section{SIMPULAN DAN SARAN}

Berdasarkan hasil analisis data dan pembahasan yang telah dilakukan, maka dapat disimpulkan hasil penelitian sebagai berikut. 1) Model pembelajaran kooperatif tipe TGT berbantuan software Cabri 3D menghasilkan prestasi belajar lebih baik dibandingkan model pembelajaran kooperatif tipe TGT dan model pembelajaran langsung, serta model pembelajaran kooperatif tipe TGT menghasilkan prestasi lebih baik dibandingkan dengan model pembelajaran langsung. 2) Siswadengankemampuan koneksi matematis kategori tinggidan siswa dengan kemampuan koneksi matematis kategori sedangmempunyai prestasi belajar yang sama, sementara keduanyamempunyai prestasi belajar yang lebih baik dibandingkan siswadengankemampuan koneksi matematis kategori rendah. 3) Pada masingmasing tipe kemampuan koneksi matematis (tinggi, sedang, dan rendah), penerapan model pembelajaran kooperatif tipe TGT berbantuan software Cabri 3D menghasilkan prestasi belajar lebih baik dibandingkan model pembelajaran kooperatif tipe TGT dan model pembelajaran langsung, serta model pembelajaran kooperatif tipe TGTmenghasilkanprestasi lebih baik dibandingkan dengan model pembelajaran langsung.4) Pada masing-masing model pembelajaran (TGT berbantuan software Cabri 3D, TGT,dan langsung), siswa dengankemampuan koneksi matematis kategori tinggidan siswa dengan kemampuan koneksi matematis kategori sedangmempunyai prestasi belajar yang sama, sementara keduanyamempunyai prestasi belajar yang lebih baik dibandingkan siswadengankemampuan koneksi matematis kategori rendah. 
Berdasarkan simpulan hasil penelitian di atas, penulis dapat memberikan beberapa saran yang dirangkum sebagai berikut.1) Mengacu pada hasil penelitian ini, model pembelajaran TGT berbantuan software Cabri 3D dan TGT memberikan prestasi belajar yang lebih baik daripada model pembelajaran langsung. Melihat hal ini, guru mata pelajaran matematika disarankan untuk menggunakan model pembelajaran tersebut dalam pembelajaran matematika. Selain itu, guru hendaknya memperhatikan kemampuan koneksi matematis karena berpengaruh dalam prestasi belajar, serta penggunaan media pembelajaran seperti komputer dianjurkan untuk lebih sering digunakan, 2) Siswa perlu memperkaya bahan pelajaran matematika,lebih baik siswa tidak hanya mengandalkan cakupan materi yang disampaikan guru di kelas.Manfaatkan fasilitas yang ada di sekolah dengan sebaik-baiknya. Buku paket, fasilitas internet, komputer, perpustakaan dan fasilitas lainnya dapat digunakan untuk sarana meningkatkan hasil belajar.

\section{DAFTAR PUSTAKA}

Abdussakir. (2009). Pembelajaran Geometri Sesuai Teori Van Hiele. Jurnal Kependidikan dan Keagamaan vol 7 no 2,

Andriyati, F.R, \& Rudhito, M.A. (2013). Pengaruh Penggunaan Program Cabri 3D Terhadap Pemahaman Siswa Dalam Menentukan Jarak Titik ke Garis Pada Ruang Untuk Siswa Kelas X SMA. Seminar Nasional Sains dan Pendidikan Sains VIII, Fakultas Sains dan Matematika UKSW Salatiga 15 Juni 2013.

Arsyad, A. (2007). Media Pembelajaran. Jakarta: PT Raja Grafindo Persada.

Awofala, A. O. A., Fatade, A. O., \& Ola-Oluwa, S. A. (2012). Achievement in Cooperative versus Individualistic Goal-Structured Junior Secondary School Mathematics Classrooms in Nigeria. International Journal of Mathematics Trends and Technology vol 3 no 1, 7-12.

Badan Naslonal Standar Pendidikan. (2013). Laporan Hasil Ujian Nasional 2012/2013. Kementerian Pendidikan dan Kebudayaan.

Güven, B., \& Kosa, K. (2008). The Effect of Dynamic Geometry Software on Student Mathematics Teachers' Spatial Visualization Skills. The Turkish Online Journal of Educational Technology vol 7 no 4, 100-107.

Irsadi. (2012). Penggunaan Perangkat Lunak Cabri 3D Pada Pokok Bahasan Bangun Ruang Sisi Lengkung di Kelas IX SMP Negeri 24 Palembang, Seminar Nasional, FKIP Universitas Sriwijaya Palembang 26 Mei 2012.

Linto, R.L. (2012). Kemampuan Koneksi Matematis Dan Metode Pembelajaran Quantum Teaching Dengan Peta Pikiran. Jurnal Pendidikan Matematika vol 1 no 1, 83-87.

Misdalina, Zulkardi, \& Purwoko. (2009). Pengembangan Materi Integral untuk Sekolah MenengahAtas (SMA) Menggunakan Pendekatan PendidikanMatematika Realistik Indonesia (PMRI)di Palembang. Jurnal Pendidikan Matematika vol 3 no 1, 61-74.

Özsoy, N., \& Yildiz, N. (2004). The Effect of Learning Together Technique of Cooperative Learning Method on Student Achievement in Mathematics Teaching 7th Class of Primary School "Işbirlikli Öğrenme" Yönteminin Ilköğretim 7.Sinif Matematik Öğretiminde Öğrenci Başarisi Üzerine Etkisi. The Turkish Online Journal of Educational Technology vol 3 no 3, 49-54. 
Prabawanti, E. H. (2012). Eksperimentasi Model Pembelajaran Kooperatif Tipestudent Teams Achievement Division (Stad) Dan Teams Games Tournament (TGT) Pada Materi Pokok Dimensi Tiga Ditinjau Dari Aktivitas Belajar Siswa Sma Kelas X di Kabupaten Magetan Tahun Pelajaran 2011/2012. Surakarta: Tesis UNS.

Slavin, R.E. (2005). Cooperative Learning (Theory, Research, and Practice). Bandung: Nusa Media.

Subroto, T. 2011. The Use of Cabri 3D Software as Virtual Manipulation Tool in 3-Dimension Geometry Learning to Improve Junior High School Students' Spatial Ability. Proceeding. The paper had been presented at International Seminar and the Fourth National Conference on Mathematics Education 2011 "Building the Nation Character through Humanistic Mathematics Education". Yogyakarta: Department of Mathematics Education (UNY).

Tarim, K., \& Akdeniz, F. (2008). The Effects of Cooperative Learning on Turkish Elementary Students' Mathematics Achievement and Attitude Towards Mathematics Using TAl and STAD Methods. Educ. Stud. Math Vol 6 No 7, 77-91.

Tran, V.D. (2013). Effects of Student Teams Achievement Division (STAD) on Academic Achievement, and Attitudes of Grade 9th Secondary School Students Towards Mathematics. International Journal of Sciences Vol 3 no 2, 5-15.

Trianto. (2012). Mendesain Model Pembalajaran Inovatif-Profresif: Konsep, Landasan, dan Implementasinya pada Kurikulum Tingkat Satuan Pendidikan (KTSP). Jakarta: Kencana.

Wyk, M. M. V. (2011). The Effects of Teams-Games-Tournaments on Achievement, Retention, and Attitudes of Economics Education Students. Journal Social Science Vol 26 no 3, 183-193.

Zakaria, E., \& Iksan, Z. (2007). Promoting Cooperative Learning in Science and Mathematics Education: A Malaysian Perspective. Eurasia Journal of Mathematics, Science \& Technology Education Vol 3 no 1, 35-39. 